\title{
Study Habits of Higher Performing Engineering Students: A Survey
}

\author{
Neha Chitkara \\ Electronics and \\ Communication Department \\ IIIT, Delhi
}

\author{
Priya Singhal \\ Electronics and \\ Communication Department \\ IIIT, Delhi
}

\author{
Priya Aggarwal \\ Electronics and \\ Communication Department \\ IIIT, Delhi
}

\begin{abstract}
Education is any act or experience that has a formative effect on the mind, character or physical ability of an individual. The education is expected to be in tune with the emerging needs of the society. Education is seen to play role both in personal life and social and economic well-being of community. The real meaning of education is to gather Knowledge. However, the purpose learning has always been ignored. Purpose learning comes by forming good study habits. Students cannot learn quickly and thoroughly, until they inculcate good study habits in themselves. Engineering is a rigorous curriculum, but the key to succeed is studying smarter and harder. This paper describes the study habits which can help a student learn more effectively, thereby, in the process achieving higher grades. The literature review is done and the material is compiled from various research journals, articles and surveys. This paper equates the higher performing students to those having higher grades and knowledge. Also, a survey was conducted to support the theories. The survey results are presented in the end.
\end{abstract}

\section{General Terms}

Effective studying, Study Habits, Engineering

\section{Keywords}

Study habits; Time management; Class attendance; Note taking; Engineering; CGPA

\section{INTRODUCTION}

The excellent academic performance is an ultimate goal of study for every student because it provides the halfway of success in the future [1]. Learning how to study involves putting away the habits and ideas which have made study unpleasant and burdensome, and talking on habits and ideas which make study more pleasant and fruitful. Students need to know how they can earn the achievement in academic performance. Many educators explored that students do not know how to think and study properly and effectively [4]. Many students proceed for the higher education without developing the habit of scheduling their study time. Thus, many talents and potentialities remain underdeveloped due to less attention given to their academic and personal growth [2]. These traits set apart the really successful students from the average ones. It has been identified that good study habits include skills such as time management, self-discipline, concentration, memorization, effort and many more. To evaluate the quality of learners, the standard measurement used by various institutions is Cumulative Grade Point Average (CGPA) which ranges from the lowest 0 to the maximum 10 [3]. A student who scores CGPA as 10 is considered as excellent academic performer compared to the student with lower grades. A lot of research has been done which reveals that students' study habits have positive relation with their performance [2]. This reflects that if a student has the proper study habits, the assignment marks and the examination results will be of the superior level. The popular trend of social media also has significant influence on students' study habits [6]. Students can easily access into sources of knowledge or doing assignments via internet while it is also easy to involve with plagiarism. Experts agree that great success in the field of knowledge is attributed to good and consistent study habits [3]. Like any other activity, skill and dedication are the key points for learning how to learn. The objectives of this study are to describe the effective study habits of engineering students and to describe the instructor's role in building effective study skills in students.

The paper is organized as follows. Section I introduces the importance of right study habits in getting better grades, section II describes the effective study habits, section III has literature review, and section IV elucidates the instructor's role in forming these habits. Section $V$ contains the methodology of conducting the survey, section VI contains the survey results and finally the paper is concluded in section VII.

\section{EFFECTIVE STUDY HABITS}

Studying is a skill. Students must first learn these skills, practice them and develop effective study habits in order to become a high performing student [5].Developing good study habits helps students to take responsibility for the learning process, set practical goals, be aware of performance and progress, use time wisely and understands and retain content [3].Thus, studying effectively is the fundamental step in being a good student. Following are some study habits that students must inculcate in themselves in order to be higher performing students.

\subsection{Set Goals}

Students should think properly how each class fits into their college plans and what grade they want to earn in each class [7]. People who take time to develop goals are much more likely to achieve them. Students should develop a weekly study schedule and determine when they will have time to study each week.

\subsection{Time Management}

Time management plays a vital role in improving student's academic performance. Each and every student should have time management ability which includes setting goals \& priorities and being organized in using time [2]. Time management is possible only through self-motivation. 


\section{Performance $=$ Ability $*$ Motivation}

A student with very high ability but low motivation may not perform well, but a student with low ability but high motivation has higher probability of performing well. Activities like spending hours on social - networking sites performed by today's college students acts as a barrier between them and their academic performance. And due to mismanagement of time they lag behind. Students should study when they are more awake, alert and able to absorb new information. Studies conducted by Britton and Tesser (1991) [7] suggest that a student's ability to manage their time successfully and productively is explicitly related to academic performance. The better a student's time management, the better their grades and the less stress they experience in regards to their academic life [8].

\subsection{Keeping a Well-Kept Notebook Improves Grades}

A well-kept notebook is a part of good time management. Taking notes helps students organize the material covered and point out areas of weakness. This information provides students with the information needed to organize their study time more effectively. During the survey[1] conducted in one of the first year programming course it has been found that only $46 \%$ of the total students strongly agree that they take fairly complete notes in the class. Students that learn to take notes do a better job of listening while in class [5]. Note taking provides students with direction, keeps them organized, and helps them keep up with their studies.

\subsection{Review Material Frequently}

A student who does not review study material can forget $80 \%$ of what has been learned in only two weeks. The first review should come very shortly after the material was first presented and studied [3]. Repeated exposure to the material will store it in student's long-term memory. Frequent reviews throughout the course will alleviate pre-test anxiety. It also significantly reduces the time necessary to prepare for exams. Reviewing material before the next class period enables the student to identify points of confusion in the notes, which prepares them for asking the questions before the next lecture. Research has shown that reviewing new material within 24 hours of hearing increases retention of that material by about $60 \%$ [7].

\subsection{Attending Classes}

Some students believe that missing class and borrowing notes from a classmate is an effective way to get information, although it is not true always [2]. Written notes are the note taker's interpretation of the lecture, and the interpretation of two different students will not be the same. As a result, the notes from a classmate may miss important concepts and ideas. According to a study conducted by University of Northumbria in April 2005[5], Attendance of the students was generally good in the beginning of the session, but falls off through the academic year. At the beginning of the academic year $91.9 \%$ claims to attend over $75 \%$ of timetabled sessions. This falls gradually to $53.2 \%$ of students at the end of the second semester. The main reason for non-attendance was 'long gaps between classes. 0Also, according to studies, people often comprehend and retain one fourth of what they hear [8]. Thus, attending classes is always useful when it comes to learning more.

\subsection{Participation in the Class Discussion}

Class participation creates an environment in which all the students have the opportunity to learn and in which the class explores issues and ideas in depth, from a variety of viewpoints. If class includes group activities, students should participate as fully as they can [2]. Such exercises are done for student's benefit and not to provide break to the instructor. This habit also helps students to be active during the lecture hours. Here, the instructor's goal is to create conditions that enable students of various learning preferences and personalities to contribute.

\subsection{Dedicate a Specific Organised Place to Study}

If concentration is the problem of student, then the right surroundings play a very important role. Study desk or table of student should be in a quiet place - free from any kind of distraction. It has been observed in most of the students that they will concentrate better when they study in the same place every day. It is just a mind-set. For example, when one sits down at the kitchen table, he expects to eat. When one sits down in an easy chair, he watches TV, etc. Developing the habit of studying in the same place at the same time everyday help in improving concentration so does the performance [3].The study area should be free of clutter and well equipped with notebooks, textbooks, pens, pencils, and dictionary and should be well lit and free from noise and distractions.

\subsection{Don't Plagiarize}

With the advent of the Internet and easy access to almost limitless written material on every conceivable topic, suspicion of student plagiarism has begun to affect teachers at all levels, at times diverting them from the work of developing students' critical thinking abilities. Students who plagiarize do not concentrate on the learning part. All their efforts are directed towards copying an answer or an assignment and they does not learn anything from the whole procedure [6]. Thus, it is very important for the students to do the assignments themselves. This will not only facilitate learning but also will help them gain confidence in the subject.

\subsection{Finding a Study Group}

Student should never underestimate the power of his peers, especially when working through a difficult problem set or reading assignment. Material that has been discussed in the group remains in the student's mind for a longer time. Cognitive process and social emotional process helps in interaction and thus, brings achievement. According to a survey by Maryellen Weimer, $\mathrm{PhD}$ in Teaching and Learning[8], 85 percent of the of the students who participated in group study preparing for the first exam in this class believed that being in a group helped their grade. However, some precautions must be taken while making a study group. The study group should not have more than 3-6 people, should not be based on friendship but should be formed with people who stay alert during classes, should be held in places free of distraction and should be no more than 2 -3 hours at a time [7].

\subsection{Study Like a Story}

Building the concepts like a story would help in understanding the concepts in a better manner. Students should put first thing first [3] which means start from the beginning and further move ahead by building one concept 
over the other. Students should be able to connect to other things when everything is visualized while studying. Analogies should be built for better retention and deeper understanding of the subjects.

\subsection{Understanding your Strength and Weakness}

Everyone has some strength and some weaknesses. Knowing the areas where one is strong and the areas where one needs assistance can help the students immensely in prioritizing their time appropriately and seeking help wherever required. Self-knowledge and introspection are powerful mediums which can impact the grades of the students hugely [7]. A major difficulty lies when students find difficulty in acknowledging their weakness. The instructor can help students in acknowledging their weakness by talking periodic quizzes or counselling them.

\section{LITERATURE REVIEW}

According to an article published in the Research Journal of Engineering education [6], distractibility, inquisitiveness, and compulsiveness in test and homework situations are effective indexes to determine the effectiveness of the study habits of students. It was concluded that students who earn the highest grades, will tend to be less distractible and more inquisitive. No significant gender differences were found for aptitude or grades, but women scored higher on the compulsiveness study habits scale than men.

\section{ROLE OF INSTRUCTOR IN PROMOTING GOOD STUDY HABITS}

Good study habits do not come by birth. It is the duty of instructor and the parents to inculcate good study habits in a student. Good teachers make their students highly independent. In other words, they train the students "how to learn" on their own. Students develop good study habits by observing others and learning from others. So it is important for the teachers to pay attention on developing good study skills in their students. Instructor can inculcate the habits of time management in the students by giving assignments with stringent deadlines. Similarly, they can make the students do quality work by taking strict actions on them if they plagiarize. The instructor can force the students to participate in the class discussion by incorporating some active learning exercises in the classroom. Students should be appreciated in their classes for using good techniques of study so that they may be an example for other students.

\section{METHODOLOGY}

Approximately 264 students of varied engineering colleges were enrolled in the unit. The cohort comprised 118 (44.7\%) males and $146(55.3 \%)$ females. The survey results were accumulated via different modes- online and offline, included students of varying engineering .The questionnaire consisted of 20 multiple choice questions and 2 extended text type questions. Interaction was done via google survey form, distributing the questionnaire to the students of various colleges and also interacting with the students' one on one. The higher performing students were chosen out of the results and the analysis was based on those students.

Assumption - An assumption is made that the results are from a scenario where evaluation pattern is in-line with the knowledge that a student has absorbed during the course and that the CGPA is the reflection of the students learning. In this section, the analysis of survey data is reported and it is compared with the various study habits revealed in literature.

\section{RESULTS}

The results have been described in the same way as done in the literature survey above. Each heading has been described in 3 parts. The first part lists the questions asked in the survey, the second part gives the results and the third part describes the inferences from the result.

\subsection{Time Management}

Questions Asked: How well are you able to follow your planned time schedules? When do you prefer to study? Which time you prefer more for study? Around how many hours do you spend on self studies in a day? Result: By an overwhelming margin, the time of night that most students $(57 \%)$ find "very productive" for study or homework. The other students (43\%) find the time of day very productive. $60 \%$ prefer to study daily in striking contrast to the mere $40 \%$ students who like to cram in the end. A vast majority of students follow the timetable they set for themselves with $21 \%$ students strictly following their schedule followed by $50 \%$ students who try to stick to the timetable.

Inference: A student's ability to manage their time successfully and productively is explicitly related to academic performance and this can be inferred from the results as well. Maintaining a time table keeps the student organized. The students who are organized in their time schedules do fairly well in their exams. It majorly depends on students as well as how much professor pushes them to do so. Of those students, about one-third expected to work more than 10 hours a week.

\subsection{Keeping a Well-Kept Notebook Improves Grades}

Questions Asked: From where do you prefer to study? Result: Only $34 \%$ students said that they prefer to study from their own notes others $(29 \%)$ said that they study through online sources and $37 \%$ prefer to study from book. Inference: In this era, where everyone is having access to the internet, student finds internet surfing as an interesting way to study. A mixed response was received here. Students who made self notes in-class or out-class as well as referred the books for studying had higher grades. Thus, preserving the absolute best of older forms as well as incorporating the new trends is required to get the best of both worlds for enhancing the student's learning as well as his grade.

\subsection{Review Material Frequently}

Questions Asked: Do you revise the content being taught in the class before going to the next class? Result: The result shows that only $7 \%$ students always revise the content before going to class .Only $13 \%$ revise the material very often and majority $(55 \%)$ of students sometimes they revise the material. and $25 \%$ said that they don't revise. Inference: It has been assumed that if students revise material than concepts of subject become stronger but this is not the case now. Mostly students prefer to study in the free time. The only thing that the instructor can do is to add surprise quizzes weightage in the course assessment so as to inculcate this study habit in the students. 


\subsection{Attending Classes}

Questions Asked: Do you miss classes? Result: The result shows that most of the students (65\%) miss some of their classes in contrast to those who never miss even a single class (13\%). Inference: It has been observed by the researchers that the students, who attend classes, become good students who can take some responsibility and take their educations seriously. This can be seen from the results as well.

\subsection{Participation in the Class Discussion}

\section{Questions Asked: Do you participate in the class discussion?} You prefer to ask questions? Result: The result shows that $13 \%$ student always, $40 \%$ student very often, $40 \%$ students sometimes and $6 \%$ students never participate in the class. $23 \%$ students ask questions anonymously $62 \%$ directly to teacher, and $14 \%$ never care about asking questions. Inference: High performing students know that what are their weaknesses and they don't hesitate to ask questions directly to the instructor. Here, a mixed response of student's participation in the class is received. This shows that there is most of the high performing students participate in the class often resulting in their higher grade.

\subsection{Dedicate a Specific Organised Place to Study}

Questions Asked: Where do you prefer to study? How well organised is your study area? Result: The survey also asked students about what strategies they used to organise in their work. While most said they sometime remain organised in their study area (49\%), always $(37 \%)$, nearly $9 \%$ never organised and $(6 \%)$ said that they don't have specific study area. When asked about their preferred study spaces, $36 \%$ students study same place everyday, $31 \%$ students study place depends on their mood, $23 \%$ students study at the place by seeing its surrounding area and $11 \%$ students said that they study at different locations. Inference: Students were asked to rate the location of place for study but these results do not necessarily indicate which places are used most often. Mostly students said that sometimes they remain organised in their study area. It is an individual's choice and doesn't impact performance tremendously, though it helps to keep area organized.

\subsection{Don't Plagiarize}

Questions Asked: How do you do your assignments Result: In totality, 75\% students do their assignments by themselves as opposed to $25 \%$ who plagiarize. Inference: Majority high performers don't involve themselves in the act of plagiarism. This helps them in doing quality work which is the key to success. Thus, there should be strict rule of plagiarism in the institute so as to inculcate study skill of quality work in the student

\subsection{Finding a Study Group}

Questions Asked: Do you prefer to study individually or in a group?

Result: The students nominated whether they do work individually or in the group. Most students indicated that they work alone $(69 \%)$ and others indicated that they work in the group.

Inference: Mostly high performing students don't study in a group. They start from self study and whenever they face any difficulty, they discuss it in the group or with the instructor. This helps them understand the concepts first and then build on them using the group as a platform for further discussion.

\subsection{Study Like a Story}

Questions Asked: Do you gather more information about the topic you are studying from sources like technical papers and other books? Do you cram the concept or try to learn by relating it to the real world? Result: The question of studying by relating the concept to the real world got majority of student lying in the average scale. However, majority of students admitted to studying from technical sources wherever required. Inference: There is not a clear inference of students' theory connection with the real world. As per the gathering of information is concerned, it depends on the course material, whether or not there is a need to understand that concept.

\subsection{Understanding One's Own Strengths and Weaknesses}

Questions Asked: Do you take help from teaching assistant or instructor?

Result: Around 4\% said that they take help from other. Majority (64\%) of students said that they sometimes take help and $18 \%$ said that always and $14 \%$ said that never. Inference: Understanding strength and weakness of one's self is very important and wherever student is lagging he should approach the appropriate person for the help. Majority of the students who are high performers don't shirk away from taking help. This indicates that they know their weaknesses, admit them, take help and improve. This help can be in the non-technical field as well.

The results have been concluded in the following table. The figures shown in the table are percentages.

Table 1. Questions asked and Results

\begin{tabular}{|c|c|c|c|}
\hline \multicolumn{4}{|c|}{ Time Management } \\
\hline \multicolumn{4}{|c|}{ How well are you able to follow your planned time schedules? } \\
\hline Strictly follow & 21 & Rarely follow & 13 \\
\hline Sometimes follow & 50 & $\begin{array}{l}\text { I don't make time } \\
\text { schedules }\end{array}$ & 16 \\
\hline \multicolumn{4}{|l|}{ When do you prefer to study? } \\
\hline Only a week before the exam & 40 & Study regularly & 60 \\
\hline \multicolumn{4}{|c|}{ Around how many hours do you spend on self studies in a day? } \\
\hline Study before the exam & 22 & $2-3$ hours & 25 \\
\hline $1-2$ hours & 34 & 3 hours or above & 19 \\
\hline \multicolumn{4}{|c|}{ Inclination towards engineering } \\
\hline \multicolumn{4}{|c|}{ Why did you take up engineering? } \\
\hline $\begin{array}{l}\text { Because I like technological } \\
\text { innovation }\end{array}$ & 71 & $\begin{array}{l}\text { Because I was not } \\
\text { having any other } \\
\text { option than taking up } \\
\text { engineering }\end{array}$ & 12 \\
\hline $\begin{array}{l}\text { Because of guardians' } \\
\text { pressure }\end{array}$ & 5 & Others & 13 \\
\hline \multicolumn{4}{|c|}{ Which knowledge do you like to gather more? } \\
\hline Factual knowledge & 27 & $\begin{array}{l}\text { Experimental } \\
\text { knowledge }\end{array}$ & 73 \\
\hline \multicolumn{4}{|c|}{$\begin{array}{l}\text { How much research oriented are you (Rate on a scale of } 4(4 \text { is for } \\
\text { Maximum Research orientation)? }\end{array}$} \\
\hline 1 & 24 & 3 & 35 \\
\hline 2 & 36 & 4 & 7 \\
\hline \multicolumn{4}{|c|}{$\begin{array}{l}\text { Do you gather more information about the topic you are studying } \\
\text { from sources like technical papers and other books? }\end{array}$} \\
\hline Yes, Sometimes & 88 & Never & 12 \\
\hline \multicolumn{4}{|c|}{ Ability to Organize } \\
\hline \multicolumn{4}{|c|}{ Where do you prefer to study? } \\
\hline same place everyday & 26 & Depends on the & 31 \\
\hline
\end{tabular}




\begin{tabular}{|c|c|c|c|}
\hline & & mood & \\
\hline Different locations & 11 & $\begin{array}{l}\text { Depends on the } \\
\text { surrounding area }\end{array}$ & 23 \\
\hline \multicolumn{4}{|c|}{ How well organized is your study area? } \\
\hline Not at all & 9 & Very much & 38 \\
\hline A Little & 48 & $\begin{array}{l}\text { No specific study } \\
\text { area }\end{array}$ & 6 \\
\hline \multicolumn{4}{|c|}{ Quality Work } \\
\hline \multicolumn{4}{|c|}{ How do you do your assignments? } \\
\hline From day one, myself & 27 & $\begin{array}{l}\text { Myself but Leave the } \\
\text { work till time is due }\end{array}$ & 47 \\
\hline Copy others assignments & 23 & $\begin{array}{l}\text { I don't do } \\
\text { assignments }\end{array}$ & 4 \\
\hline \multicolumn{4}{|c|}{ Pro activeness } \\
\hline \multicolumn{4}{|c|}{ Do you prefer to study in a group or alone? } \\
\hline Group & 31 & Alone & 69 \\
\hline \multicolumn{4}{|c|}{ Do you participate in class discussions? } \\
\hline Not at all & 6 & Very often & 40 \\
\hline Sometimes & 40 & Always & 13 \\
\hline \multicolumn{4}{|c|}{ Do you revise the content being taught in class? } \\
\hline Not at all & 25 & Very often & 13 \\
\hline Sometimes & 55 & Always & 7 \\
\hline \multicolumn{4}{|l|}{ Do you miss classes? } \\
\hline Not at all & 13 & Very often & 13 \\
\hline Sometimes & 65 & Always & 9 \\
\hline \multicolumn{4}{|c|}{ Understanding of one's own strengths and weaknesses } \\
\hline \multicolumn{4}{|c|}{ Do you take help from teaching assistant or instructor? } \\
\hline Not at all & 14 & Very often & 19 \\
\hline Sometimes & 64 & Always & 4 \\
\hline
\end{tabular}

\section{CONCLUSION}

Students must have Meta cognitive skills such as ability to plan, monitor their success, know their weaknesses and evaluate themselves in order to fall into the category of high performing students. Student study habits present a complex picture. In this paper, relationships between students' final results and their study habits are investigated. The findings show that students engaged in a wide range of study behaviours in terms of time spent and use of resources. Clear connection between learning in the classroom and students' work outside of class was recognized.

\section{REFERENCES}

[1] Larry G. Ricchards, Herbert C. Richards, a d Dana C. Sheridan, "Predicting Success in a First Year Engineering Course: The Role of Study Habits"29'Th ASEE/IEEE Frontiers in Education Conference 1999.

[2] Covey, Stephen R," The 7 Habits of Highly Effective Students" (2008) The Leader in Me: How Schools and Parents around the World are Inspiring Greatness, One Child at a Time. Free Press, Detroit MI

[3] M. Young, "The Technical Writer's Handbook". Mill Valley, CA: University Science, 1989.

[4] Poor Sleep Can Negatively Affect a Student's Grades, Increase the Odds of Emotional and Behavioral Disturbance,American Academy of Sleep Medicine,2008

[5] www.northumbria.ac.uk/static/worddocuments/ardocs/30 4165.doc

[6] Harry N. Blumner and Herbert C. Richards,"Study Habits and Academic Achievement of Engineering Students",The research journal for engineering education, Vol 86,Issue 2,Jan 2013

[7] Britton, B. K., \& Tesser, A. (1991). Effects of time management practices of college grades. Journal of Educational Psychology, 83, 405-410

[8] http://www.facultyfocus.com/articles/teaching-andlearning/the-elusive-benefits-of-study-groups/ 